\title{
BMJ Open Is coffee consumption associated with a lower risk of hyperuricaemia or gout? A systematic review and meta-analysis
}

\author{
Yi Zhang, ${ }^{1}$ Tuo Yang, ${ }^{1}$ Chao Zeng, ${ }^{1}$ Jie Wei, ${ }^{2}$ Hui Li, ${ }^{1}$ Yi-lin Xiong, ${ }^{1}$ Ye Yang, ${ }^{1}$ \\ Xiang Ding, ${ }^{1}$ Guanghua Lei ${ }^{1}$
}

To cite: Zhang Y, Yang T, Zeng $C$, et al. Is coffee consumption associated with a lower risk of hyperuricaemia or gout? A systematic review and meta-analysis. BMJ Open 2016;6:e009809.

doi:10.1136/bmjopen-2015009809

- Prepublication history for this paper is available online. To view these files please visit the journal online (http://dx.doi.org/10.1136/ bmjopen-2015-009809).

Yi Zhang and Tuo Yang contributed equally to this article.

Received 24 August 2015 Revised 29 April 2016 Accepted 31 May 2016

\section{(1) crossmatk}

${ }^{1}$ Department of Orthopaedics, Xiangya Hospital, Central South University, Changsha, Hunan Province, China ${ }^{2}$ Department of Epidemiology and Health Statistics, School of Public Health, Central South University, Changsha, Hunan Province, China

Correspondence to Dr Guanghua Lei; Igh9640@sina.cn

\section{ABSTRACT}

Objectives: To examine the associations of coffee consumption with the serum uric acid (SUA) level, hyperuricaemia (HU) and gout.

Design: Systematic review and meta-analysis.

Data sources and study eligibility criteria: A comprehensive literature search up to April 2015, using PubMed and EMBASE databases, was conducted to identify the observational researches that examined the associations of coffee consumption with the SUA level, HU and gout. The standard mean difference (SMD), OR, relative risk (RR) and their corresponding $95 \% \mathrm{Cls}$ for the highest and the lowest categories of coffee intake were determined.

Results: A total of 11 observational studies $(6$ crosssectional, 3 cohort and 2 case-control studies) were included in this systematic review and meta-analysis. The combined SMD suggested that there was no significant difference between the highest and the lowest coffee intake categories in terms of the SUA level $(S M D=-0.09,95 \% \mathrm{Cl}-0.23$ to $0.05 ; p=0.21$ ). Meanwhile, the overall multivariable adjusted $\mathrm{OR}$ for HU showed no significant difference between the highest and the lowest coffee intake categories $(\mathrm{OR}=0.84,95 \% \mathrm{Cl} 0.65$ to $1.09 ; \mathrm{p}=0.20)$. However, the overall multivariable adjusted RR for gout showed a significant inverse association between coffee consumption and the incidence of gout ( $R R=0.43$, $95 \% \mathrm{Cl} 0.31$ to $0.59, \mathrm{p}<0.001$ ).

Conclusions: Current evidences are insufficient to validate the association between coffee consumption and a lower risk of HU. Owing to the limited number of studies, the available data show that coffee consumption may be associated with a lower risk of incident gout. Further well-designed prospective researches and randomised controlled trials are therefore needed to elaborate on these issues.

\section{INTRODUCTION}

Uric acid (UA) is the final product of purine metabolism in human beings, while the concentration of serum uric acid (SUA) is determined by the production and excretion of urate. Hyperuricaemia (HU) is commonly recognised as a risk factor for many chronic

\section{Strengths and limitations of this study}

- This is the first systematic review and meta-analysis aiming at the associations of coffee consumption with the risk of hyperuricaemia and gout based on the most comprehensive literature search until now.

- The included studies were analysed on the basis of adjusted results and a large number of samples.

- The present study reveals the deficiency of current evidences, which can serve as an indication for further relative researches.

- Owing to the limitation of relevant literature, only a few studies were qualified for this meta-analysis.

diseases such as hypertension, ${ }^{1-3}$ diabetes, ${ }^{4-5}$ cardiovascular disease, ${ }^{6-9}$ metabolic syndrome (MetS) ${ }^{10}$ chronic kidney disease ${ }^{11}$ and insulin resistance. ${ }^{12}$ Epidemiological evidence showed that about $21.4 \%$ of American adults suffer from $\mathrm{HU},{ }^{13}$ while the prevalence of $\mathrm{HU}$ in some Asian countries ranged from $13 \%$ to $25.8 \% .{ }^{14-18} \mathrm{HU}$ is also known as the precursor of gout, a common inflammatory arthritis mediated by the crystallisation of UA in joints. ${ }^{19}$ Generally speaking, gout consists of four phases, namely asymptomatic HU, recurrent attacks of acute arthritis, intercritical gout and chronic tophaceous gout. ${ }^{20}$ In view of the substantial burden incurred by the healthcare of gout and the growing trend of its incidence, ${ }^{19}$ an in-depth understanding of the aetiology and risk of gout will be greatly helpful for its early prevention and treatment. However, the specific pathogenesis of $\mathrm{HU}$ and gout has not yet been fully elucidated.

Coffee is a sort of soft beverage widely consumed in the world. For example, nearly half of the Japanese adults drink coffee on a daily basis, ${ }^{21}$ and over $50 \%$ of Americans consume an average coffee intake of 1-2 cups per day. ${ }^{22}$ Coffee contains more than 1000 types of compound, including caffeine, carbohydrates, lipids, nitrogenous compounds, 
vitamins, minerals, alkaloids and phenolic compounds. ${ }^{23}$ It is worth noting that coffee is believed to be beneficial for patients with Parkinson's disease, cardiovascular disease, urolithiasis and type 2 diabetes mellitus. ${ }^{24-27}$ On the other hand, it may be also related to the development of cancer, as well as increased blood pressure, plasma homocysteine concentrations, serum total and low-density lipoprotein cholesterol concentrations. ${ }^{28-31}$ With respect to the case of $\mathrm{HU}$ or gout, several epidemiological studies have investigated their potential associations with coffee consumption, ${ }^{32-42}$ but no consistent conclusion was reached. Nevertheless, some researchers have tried to elucidate the relative mechanisms. As a major component of coffee, caffeine (1,3,7-trimethyl-xanthine) was demonstrated to competitively inhibit xanthine oxidase in rats. ${ }^{43}$ Meanwhile, the phenol chlorogenic acid in coffee might contribute to the inverse coffee-SUA relationship. ${ }^{36-38}$ Thus, the present systematic review and meta-analysis of observational studies aimed at investigating the associations of coffee consumption with SUA concentration, and the risk of $\mathrm{HU}$ or gout. It was hypothesised that coffee intake is associated with a lower SUA concentration, and a lower risk of $\mathrm{HU}$ or gout.

\section{MATERIALS AND METHODS}

\section{Search strategy}

This systematic review and meta-analysis was performed in accordance with the Preferred Reporting Items for Systematic review and Meta-analyses (PRISMA) statement. ${ }^{44}$ The electronic databases of PubMed and EMBASE were searched through in April 2015 using a series of logical combinations of keywords and in-text words that are related to UA ('uric acid', 'gout', 'hyperuricemia', 'urate', 'hyperuricaemia') and coffee ('coffee', 'java', 'caffea', 'caffe'). No language restriction was imposed. The references of the retrieved articles and reviews were evaluated.

\section{Study selection}

Two researchers reviewed the titles, abstracts and full texts of all retrieved studies independently. Disagreements were resolved through discussions and mutual consultations. All eligible studies were supposed to meet the following criteria: (1) observational studies (case-control, cohort or cross-sectional study); (2) the exposure of interest was coffee; (3) the outcome of interest was SUA level, frequency of HU or gout. The exclusion criteria for this study were as follows: (1) duplicated or irrelevant articles; (2) reviews, letters, case reports or non-human studies; (3) inaccessibility of full text.

\section{Data extraction}

Available information and outcomes of each study were screened by the two researchers independently. The extracted data included the first author, year of publication, location, age, gender, sample size, study design, exposure definition, adjustments and outcome. The methodological quality of included studies was evaluated in accordance with the Newcastle-Ottawa Scale (NOS), ${ }^{45}$ which is developed for assessing the quality of nonrandomised studies based on three broad perspectives: the selection of study groups; the comparability among different groups and the ascertainment of either the exposure or outcome of interest. Disagreements with respect to the methodological quality of results, if any, were resolved by discussion and mutual consultation. The primary outcome was the difference in SUA concentrations between the higher and the lower categories of coffee intake or between the higher and the noncoffee intake categories. The secondary outcome of interest was the OR of $\mathrm{HU}$ and relative risk (RR) of gout between the higher and the lower categories of coffee intake or between the higher and the non-coffee intake categories. Since the included studies adopted different rules of coffee intake categorisation, only data from the comparison between the highest and the lowest coffee intake categories, which were defined by the original study, were extracted.

\section{Statistical analyses}

The outcome measures investigated in this meta-analysis were the SUA level, the OR of $\mathrm{HU}$ and the RR of gout. The standard mean difference (SMD) and its corresponding 95\% CI for SUA were calculated. The pooled OR of $\mathrm{HU}, \mathrm{RR}$ of gout and their related 95\% CI were also calculated. The original $\mathrm{OR}$ and $\mathrm{RR}$ values were logarithmically transformed for calculation. Then, anti-ln was performed to the combined value to generate the pooled OR and RR. The most multivariable adjusted $O R$ and $R R$ values reported in the original study were extracted for calculation if more than one was reported. The homogeneity of effect size across trials was tested by $Q$ statistics $(p<0.05$ was considered heterogeneous). If significant heterogeneity was observed among studies, the random-effects model was

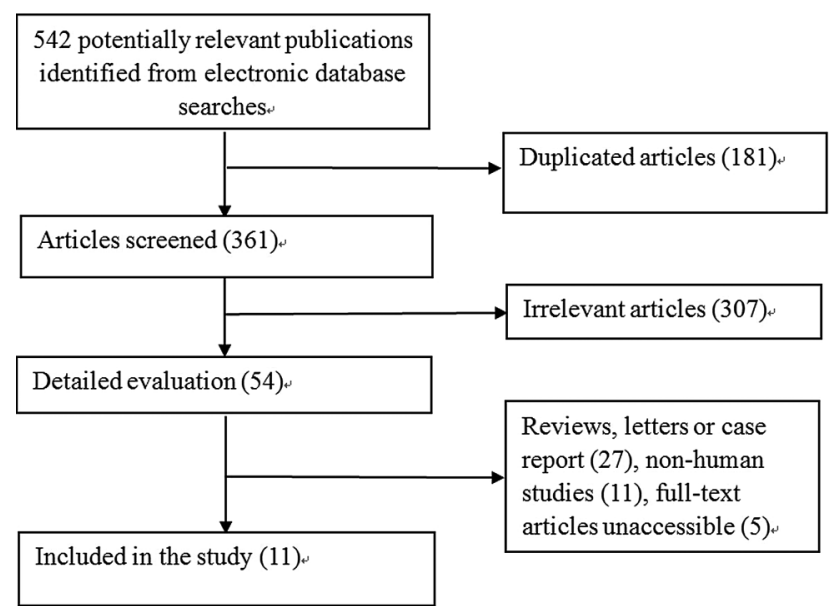

Figure 1 Flow chart for the identification of studies that were included in this systematic review and meta-analysis. 
Table 1 Characteristics of the individual studies included in this systematic review and meta-analysis

\begin{tabular}{|c|c|c|c|c|c|c|c|c|}
\hline $\begin{array}{l}\text { First author } \\
\text { year of } \\
\text { publication }\end{array}$ & Location & $\begin{array}{l}\text { Age } \\
\text { years }\end{array}$ & $\begin{array}{l}\text { Male } \\
(\%)\end{array}$ & $\begin{array}{l}\text { Sample } \\
\text { size }\end{array}$ & Study design & Exposure definition & Adjustments & Outcome \\
\hline $\begin{array}{l}\text { Muckadell } \\
1976^{32}\end{array}$ & Denmark & $40-59$ & 100 & 312 & Case-control & NA & NA & Gout (physician diagnosed) \\
\hline $\begin{array}{l}\text { Kiyohara } \\
1999^{34}\end{array}$ & Japan & 52.0 & 100 & 2240 & Cross-sectional & $\begin{array}{l}<1 \mathrm{cup} / \text { day, } 1-2 \mathrm{cups} / \text { day, } \\
3-4 \mathrm{cups} / \text { day, }>5 \mathrm{cups} / \mathrm{day}\end{array}$ & $\begin{array}{l}\text { Hospital, age, serum total } \\
\text { cholesterol, serum } \\
\text { HDL-cholesterol, serum } \\
\text { creatinine, systolic blood } \\
\text { pressure, BMI, rank, beer, } \\
\text { alcohol, smoking status, meat, } \\
\text { dairy products and green tea }\end{array}$ & SUA \\
\hline Yuan $2000^{35}$ & Taiwan & NA & NA & 96 & Case-control & Ever, never & NA & SUA \\
\hline Choi $2007^{37}$ & USA & 54.0 & 100 & 45869 & Cohort & $\begin{array}{l}0 \text { cups/day, }<1 \text { cup/day, } 1-3 \\
\text { cups/day, } 4-5 \text { cups/day, }>6 \\
\text { cups/day }\end{array}$ & $\begin{array}{l}\text { Age, total energy intake, BMI, } \\
\text { diuretic use, history of } \\
\text { hypertension, history of renal } \\
\text { failure, intake of alcohol, total } \\
\text { meats, seafood, } \\
\text { purine-rich vegetables, dairy } \\
\text { foods, total vitamin C, } \\
\text { decaffeinated coffee, tea }\end{array}$ & $\begin{array}{l}\text { Gout (gout criteria of the } \\
\text { American College of } \\
\text { Rheumatology) }\end{array}$ \\
\hline Choi $2007^{36}$ & USA & 45.0 & 46.8 & 14758 & Cross-sectional & $\begin{array}{l}0 \text { cups/day, }<1 \text { cup/day, } 1-3 \\
\text { cups/day, } 4-5 \text { cups/day, }>6 \\
\text { cups/day }\end{array}$ & $\begin{array}{l}\text { Age, sex, smoking status, BMI, } \\
\text { smoking; use of diuretics, } \\
\beta \text {-blockers, allopurinol, uricosuric } \\
\text { agents, hypertension, } \\
\text { glomerular filtration rate, alcohol, } \\
\text { total meats, seafood, dairy foods, } \\
\text { decaffeinated coffee, tea }\end{array}$ & $\begin{array}{l}\text { SUA, HU (SUA level } \\
>6.0 \mathrm{mg} / \mathrm{dL} \text { ) }\end{array}$ \\
\hline Choi $2010^{38}$ & USA & 46.0 & 0 & 89433 & Cohort & $\begin{array}{l}0 \text { cups/day, }<1 \text { cup/day, } 1-3 \\
\text { cups/day, }>4 \text { cups/day }\end{array}$ & $\begin{array}{l}\text { Age, total energy intake, BMI, } \\
\text { menopause, use of hormonal } \\
\text { replacement, diuretic use, history } \\
\text { of hypertension, intakes of } \\
\text { alcohol, sugar-sweetened soft } \\
\text { drinks, total meats, seafood, } \\
\text { chocolate, dairy foods, total } \\
\text { vitamin C, decaffeinated coffee, } \\
\text { tea }\end{array}$ & $\begin{array}{l}\text { Gout (gout criteria of the } \\
\text { American College of } \\
\text { Rheumatology) }\end{array}$ \\
\hline
\end{tabular}




\begin{tabular}{|c|c|c|c|c|c|c|c|c|}
\hline $\begin{array}{l}\text { ear of } \\
\text { Jublication }\end{array}$ & Location & $\begin{array}{l}\text { Age } \\
\text { years }\end{array}$ & $\begin{array}{l}\text { Male } \\
(\%)\end{array}$ & $\begin{array}{l}\text { Sample } \\
\text { size }\end{array}$ & Study design & Exposure definition & Adjustments & Outcome \\
\hline ham $2010^{39}$ & Japan & 62.3 & 42.6 & 11662 & Cross-sectional & $\begin{array}{l}0 \text { cups/day, }<1 \text { cup/day, } 1-3 \\
\text { cups/day, } 4-6 \text { cups/day, } \geq 7 \\
\text { cups/day }\end{array}$ & $\begin{array}{l}\text { Age, BMI, smoking, alcohol use, } \\
\text { work-related physical activity, } \\
\text { leisure-time physical activity, } \\
\text { hypertension, diabetes, eGFR, } \\
\text { seafood intake }\end{array}$ & $\begin{array}{l}\text { SUA, HU (SUA level } \\
>7.0 \mathrm{mg} / \mathrm{dL})\end{array}$ \\
\hline $\begin{array}{l}\text { Chuang } \\
2011^{40}\end{array}$ & Taiwan & $>19$ & 47.5 & 4640 & Cross-sectional & NA & NA & $\begin{array}{l}\text { SUA, HU (SUA level } \\
>7.7 \mathrm{mg} / \mathrm{dL} \text { in men and } \\
>6.6 \mathrm{mg} / \mathrm{dL} \text { in women, or } \\
\text { use of uric acid-lowering } \\
\text { drugs) gout (self-report) }\end{array}$ \\
\hline Teng $2013^{41}$ & Singapore & 57.6 & 44.3 & 483 & Cross-sectional & $\begin{array}{l}\text { Non-drinkers, monthly } \\
\text { drinkers, weekly drinkers, } \\
\text { daily drinkers }\end{array}$ & $\begin{array}{l}\text { Cholesterol, creatinine, HbA1c, } \\
\text { triglycerides, age, gender, BMI, } \\
\text { education, cigarette smoking } \\
\text { status, physical activity status, } \\
\text { hypertension at baseline, dairy } \\
\text { products, red meat, fish, alcohol, } \\
\text { green tea, black tea, soda, fruit } \\
\text { juice }\end{array}$ & $\begin{array}{l}\text { SUA, HU (SUA level } \\
>6 \mathrm{mg} / \mathrm{dL})\end{array}$ \\
\hline
\end{tabular}


Table 2 The methodological quality of cross-sectional studies in accordance with the Newcastle-Ottawa Scale (NOS)

\begin{tabular}{lllllllll}
\hline Study & Design & $\begin{array}{l}\text { Data } \\
\text { collection }\end{array}$ & $\begin{array}{l}\text { Response } \\
\text { rate }\end{array}$ & Representativeness & $\begin{array}{l}\text { Object and } \\
\text { method }\end{array}$ & $\begin{array}{l}\text { Power of } \\
\text { testing }\end{array}$ & $\begin{array}{l}\text { Statistical } \\
\text { method }\end{array}$ & $\begin{array}{l}\text { Total } \\
\text { score }\end{array}$ \\
\hline Kiyohara $^{34}$ & 1 & 1 & 1 & 0 & 1 & 0 & 1 & 5 \\
Choi $^{36}$ & 1 & 1 & 0 & 1 & 1 & 0 & 1 & 5 \\
Pham $^{39}$ & 1 & 1 & 1 & 1 & 1 & 0 & 1 & 6 \\
Chuang $^{40}$ & 1 & 1 & 1 & 1 & 1 & 0 & 1 & 6 \\
Teng $^{4}$ & 1 & 1 & 1 & 1 & 1 & 0 & 1 & 6 \\
Bae $^{42}$ & 1 & 1 & 0 & 1 & 1 & 1 & 1 & 6 \\
\hline
\end{tabular}

used; otherwise, the fixed-effects model was acceptable. The $\mathrm{I}^{2}$ statistic, which measures the percentage of the total variation across studies due to heterogeneity, was also examined $\left(\mathrm{I}^{2}>50\right.$ was considered heterogeneous). Begg's tests ${ }^{46}$ were performed to assess the publication bias, and statistical analyses were performed using STATA V.11.0 (StataCorp LP, College Station, Texas, USA). A p value equal to 0.05 was considered to be statistically significant, unless otherwise specified.

\section{RESULTS}

\section{Literature search and study characteristics}

Figure 1 demonstrates the process of study selection. A total of 542 potentially relevant publications were retrieved from the initial literature search without language restriction. On elimination of 181 duplicated articles, 361 articles were identified for detailed evaluation. Then, 307 irrelevant studies, 27 reviews, letters or case reports, 11 non-human studies and 5 articles without accessible full text were removed. Eventually, a total of six cross-sectional, three cohort and two case-control studies were included in this systematic review and meta-analysis, covering 184751 participants with 9508 cases of HU and 1757 cases of gout. Table 1 summarises the main characteristics of these 11 included studies. Their methodological qualities were shown in tables $2-4$, respectively.

\section{SMD of the SUA concentration between the highest and the lowest coffee intake categories}

Six studies reported the SUA concentration of different coffee intake categories. The combined SMD suggested that there was no significant difference in SUA between the highest and the lowest coffee intake categories ( $\mathrm{SMD}=-0.09,95 \% \mathrm{CI}-0.23$ to $0.05 ; \mathrm{p}=0.21$; figure 2 ). A substantial level of heterogeneity was observed among various studies $\left(\mathrm{p}<0.001, \mathrm{I}^{2}=84.2 \%\right)$. No evidence of publication bias was observed according to the Begg's rank-correlation test $(p=0.27)$. The weighting for some large studies is less than that for some small ones (eg, Choi and colleagues, Bae and colleagues, and Kiyohara and colleagues). It is because the weighting depends on the inverse of variance for each study in random-effects analysis. In addition, it should be highlighted that two studies contained inappropriate data for meta-analysis. Curb et $a e^{33}$ found that coffee consumption was not associated with the SUA concentration. However, Chuang et $a l^{40}$ reported that there was a negative association between coffee intake and the SUA level.

\section{OR for HU between the highest and the lowest coffee intake categories}

Four studies reported the OR for $\mathrm{HU}$ between the highest and the lowest coffee intake categories. The overall multivariable adjusted OR showed no significant difference between the highest and the lowest coffee intake categories (ln $\mathrm{OR}=-0.17,95 \%$ CI -0.43 to 0.09 ; $\mathrm{OR}=0.84,95 \%$ CI 0.65 to 1.09 ; $\mathrm{p}=0.20$; figure 3 ). No significant heterogeneity was observed among various studies $\left(p=0.26, I^{2}=22.6 \%\right)$. No evidence of publication bias was observed according to the Begg's rankcorrelation test $(\mathrm{p}=0.06)$. Nevertheless, Chuang et $a t^{40}$ supposed that coffee intake was negatively associated with HU.

\section{RR for gout between the highest and the lowest coffee intake categories}

Two prospective cohort studies reported the RR for gout between the highest and the lowest coffee intake categories. The overall multivariable adjusted RR showed a significant inverse association between coffee consumption and the incidence of gout (ln $\mathrm{RR}=-0.85,95 \% \mathrm{CI}$ -1.17 to -0.53 ; RR $=0.43,95 \%$ CI 0.31 to 0.59 , $\mathrm{p}<0.001$; figure 4). No significant heterogeneity was observed among these two studies $\left(p=0.912, I^{2}=0 \%\right)$. On the other hand, a case-control study published in 1976 suggested that the coffee consumptions of the gout group and the control group were almost equal, yet without detailed data. ${ }^{32}$

\section{DISCUSSIONS}

In the current systematic review and meta-analysis, a total of 11 independent studies were identified for examination. The quantitative synthesis of these observational studies showed that there was no significant relationship between coffee consumption and the SUA concentration or the risk of $\mathrm{HU}$, while a significant inverse association between coffee consumption and the incidence of gout was observed. 
Table 3 The methodological quality of cohort studies in accordance with the Newcastle-Ottawa Scale (NOS)

\begin{tabular}{|c|c|c|c|c|c|c|c|c|c|}
\hline \multirow[b]{2}{*}{ Study } & \multicolumn{4}{|l|}{ Selection } & \multirow[b]{2}{*}{$\begin{array}{l}\text { Comparability } \\
\text { Comparability of } \\
\text { cohorts on the } \\
\text { basis of the } \\
\text { design or } \\
\text { analysis }\end{array}$} & \multicolumn{3}{|l|}{ Outcome } & \multirow[b]{2}{*}{$\begin{array}{l}\text { Total } \\
\text { score }\end{array}$} \\
\hline & $\begin{array}{l}\text { Representativeness } \\
\text { of the exposed } \\
\text { cohort }\end{array}$ & $\begin{array}{l}\text { Selection of } \\
\text { the } \\
\text { non-exposed } \\
\text { cohort }\end{array}$ & $\begin{array}{l}\text { Ascertainment } \\
\text { of exposure }\end{array}$ & $\begin{array}{l}\text { Demonstration } \\
\text { that outcome of } \\
\text { interest was not } \\
\text { present at start of } \\
\text { study }\end{array}$ & & $\begin{array}{l}\text { Assessment } \\
\text { of outcome }\end{array}$ & $\begin{array}{l}\text { Was } \\
\text { follow-up } \\
\text { long enough } \\
\text { for } \\
\text { outcomes to } \\
\text { occur? }\end{array}$ & $\begin{array}{l}\text { Adequacy } \\
\text { of follow-up } \\
\text { of cohorts? }\end{array}$ & \\
\hline Curb $^{33}$ & 1 & 1 & 1 & 0 & 1 & 0 & 1 & 1 & 6 \\
\hline Choi $^{37}$ & 0 & 1 & 1 & 1 & 2 & 1 & 1 & 1 & 8 \\
\hline Choi $^{38}$ & 0 & 1 & 1 & 1 & 2 & 1 & 1 & 1 & 8 \\
\hline
\end{tabular}

Table 4 The methodological quality of case-control studies in accordance with the Newcastle-Ottawa Scale (NOS)

\begin{tabular}{|c|c|c|c|c|c|c|c|c|c|}
\hline \multirow[b]{2}{*}{ Study } & \multicolumn{4}{|l|}{ Selection } & \multirow{2}{*}{$\begin{array}{l}\text { Comparability } \\
\text { Comparability of } \\
\text { cases and controls } \\
\text { on the basis of the } \\
\text { design or analysis }\end{array}$} & \multicolumn{3}{|l|}{ Exposure } & \multirow[b]{2}{*}{$\begin{array}{l}\text { Total } \\
\text { score }\end{array}$} \\
\hline & $\begin{array}{l}\text { Is the case } \\
\text { definition } \\
\text { adequate? }\end{array}$ & $\begin{array}{l}\text { Representativeness } \\
\text { of the cases }\end{array}$ & $\begin{array}{l}\text { Selection of } \\
\text { controls }\end{array}$ & $\begin{array}{l}\text { Definition } \\
\text { of controls }\end{array}$ & & $\begin{array}{l}\text { Ascertainment } \\
\text { of exposure }\end{array}$ & $\begin{array}{l}\text { Same method of } \\
\text { ascertainment for } \\
\text { cases and controls }\end{array}$ & $\begin{array}{l}\text { Non-response } \\
\text { rate }\end{array}$ & \\
\hline Yuan ${ }^{35}$ & 1 & 1 & 0 & 0 & 1 & 0 & 1 & 1 & 5 \\
\hline Muckadell $^{32}$ & 0 & 1 & 1 & 0 & 1 & 1 & 1 & 1 & 6 \\
\hline
\end{tabular}


Study

ID
$\operatorname{SMD}(95 \% \mathrm{Cl}) \quad$ Weight

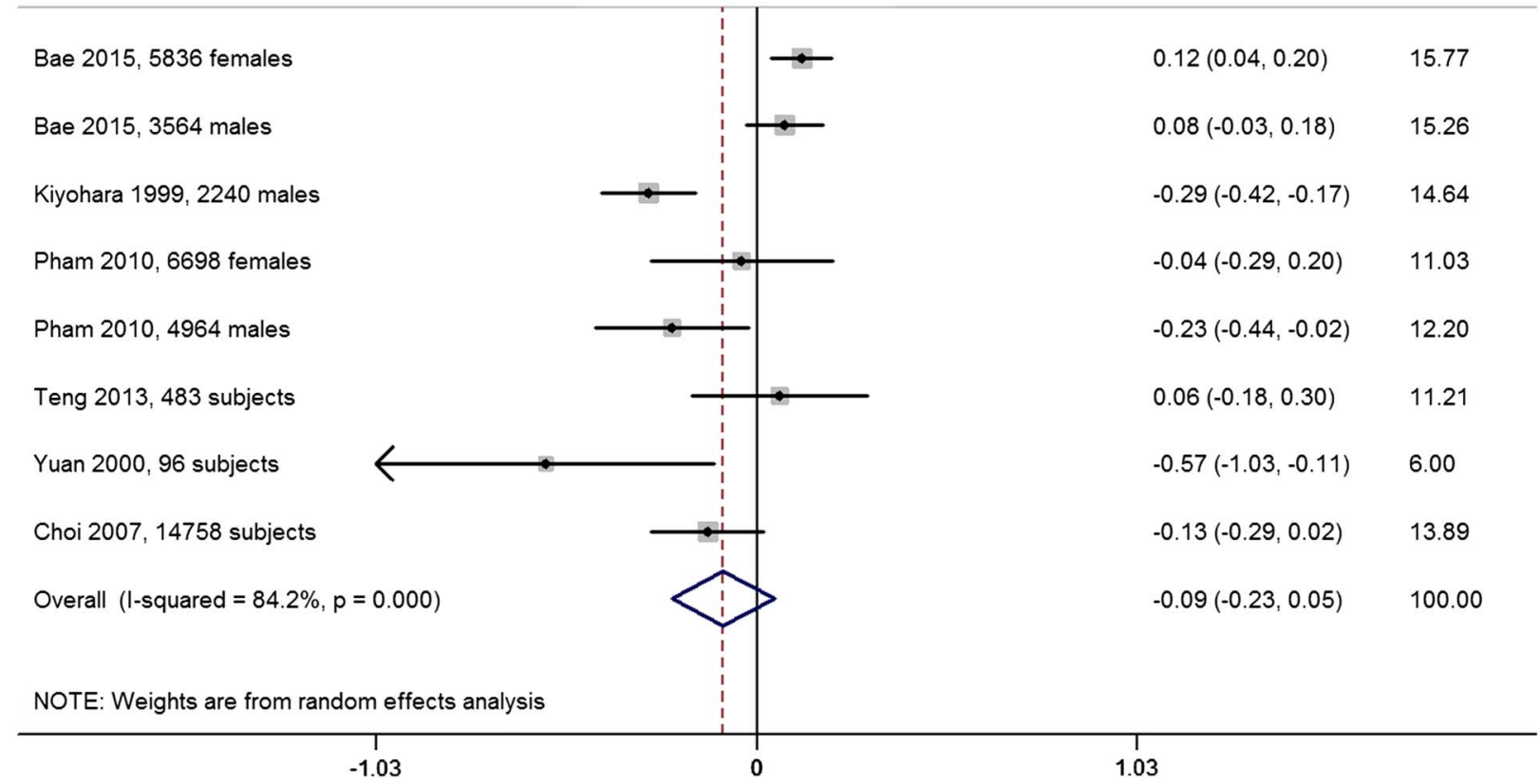

Figure 2 Forest plot of meta-analysis: SMD of SUA concentration between the highest and the lowest coffee intake categories. SMD, standard mean difference; SUA, serum uric acid.

Study

ID

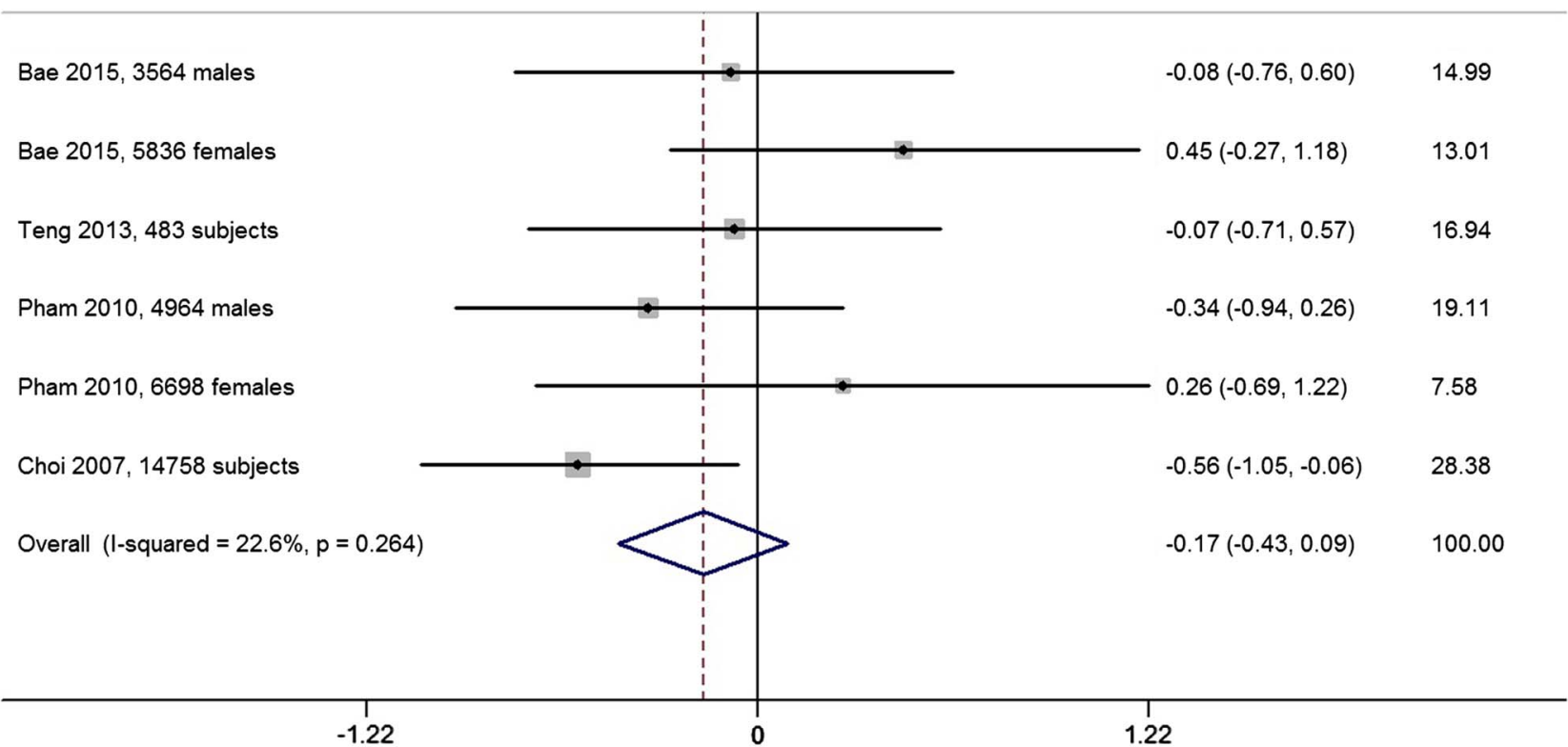

Figure 3 Forest plot of meta-analysis: overall multivariable adjusted In OR of HU between the highest and the lowest coffee intake categories. $\mathrm{HU}$, hyperuricaemia. 
Study

ID

Choi 2007, 45869 males

Choi 2010,89433 females

Overall (I-squared $=0.0 \%, p=0.912$ )
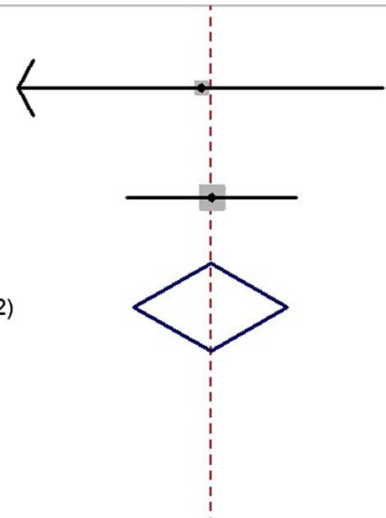

$\operatorname{Ln} \mathrm{RR}(95 \% \mathrm{Cl})$

$-0.89(-1.66,-0.13)$

$-0.84(-1.20,-0.49)$

$-0.85(-1.17,-0.53)$

100.00

$-1.66$

$\%$

Weight

Figure 4 Forest plot of meta-analysis: overall multivariable adjusted In RR of gout between the highest and the lowest coffee intake categories. $\mathrm{RR}$, relative risk.

At the level of clinical observational research, disagreements with respect to the coffee-SUA and coffee-HU associations still remain. To the best of our knowledge, the majority of previous studies suggested that coffee intake was associated with a lower level of SUA ${ }^{34-36} 3940$ and a lower frequency of HU. ${ }^{36} 3940$ However, the aforementioned relationships did not appear significant based on the findings of this study. For the coffee-gout association, the number of relevant studies is limited (only two studies); meanwhile, although these studies were both large sample-sized prospective studies, they were conducted for males and females separately. ${ }^{37} 38$ The available data showed that coffee consumption may be associated with a lower risk of incident gout. Nevertheless, more studies are needed to verify this finding. Interestingly, a prospective controlled study with four consecutive trial periods that composed of two filtered coffee $600 \mathrm{mg} /$ day and two coffee abstention proved that SUA was increased during one coffee intake period but decreased during the two coffee abstention periods. ${ }^{47}$ This result prompts that the impact of coffee on SUA is dynamic and variable over time.

Moreover, some deficiencies of current evidences must be noted. First, there is no large sample-sized prospective cohort study aiming at the coffee-SUA and coffee-HU associations. The nature of cross-sectional or casecontrol design precludes causal relationships. This might partly explain why the significant inverse association was only found in the coffee-gout rather than the coffee-HU relationship, since HU is known as the precursor of gout. Second, a substantial level of heterogeneity was observed in figure 2 forest plot and the reasons are complicated. Although the included studies were adjusted for a lot of confounding factors, the selection of these factors is not always consistent. Some studies even did not report the adjusted factors at all. ${ }^{32} 33 \quad 3540$ The classification of coffee intake varied among various studies. Coffee consumption was mostly assessed by the number of cups of daily coffee intake. However, it can hardly evaluate the concentration of each kind of coffee and the cup size referred by each research. Furthermore, the definitions of outcome were not uniform either. All these issues might contribute to the root causes of the substantial level of heterogeneity. Third, many studies were not adjusted for sufficient confounding factors appropriately. Most studies ignored the MetS or the MetS components, since MetS is associated with coffee consumption ${ }^{48}$ and the concentration of SUA. ${ }^{49}$ In addition, as an important indicator for dietary factors, the total caloric or energy intake was only adjusted in three researches. ${ }^{37} 38$ 42 Moreover, the impact of coffee on SUA might be complicated by the sugar sweetener and milk. Choi et $a \bar{l}^{0}$ have found that sugar-sweetened soft drinks are positively associated with HU, while dairy consumption is inversely correlated with HU and gout. ${ }^{51} 52$ However, not all the included studies were adjusted for these two essential factors. As a consequence, all the above discussions may weaken the reliability of our results.

Generally speaking, the mechanism of coffee consumption on the regulation of SUA concentration is not certain. First, as the major component of coffee, caffeine (1,3,7-trimethyl-xanthine) is a kind of methyl-xanthine, and was demonstrated to competitively inhibit xanthine oxidase in rats. ${ }^{43}$ Furthermore, in comparison with the control group, the patients with asthma who were treated with theophylline (1,3-dimethyl-xanthine) displayed a significant increase in the SUA level $(p<0.001),{ }^{53}$ although the caffeine-HU and caffeine-gout relationships were still 
debatable. ${ }^{34}$ 36-38 42 Second, coffee contains substantial amounts of potassium, magnesium and phenol chlorogenic acid (a strong antioxidant), which are all factors that may worsen insulin resistance. In addition, the phenol chlorogenic acid is associated with a lower concentration of plasma glucose and oxidative stress. All the above aspects may contribute to the inverse coffee-SUA association. ${ }^{36-38}$ Third, the non-caffeine xanthines in coffee may also inhibit UA synthesis. ${ }^{34}$ However, these potential mechanisms should be verified by further research.

The strengths of this systematic review and meta-analysis are mainly reflected from the following aspects. First, this is the first systematic review and meta-analysis aiming at the associations of coffee consumption with the risk of $\mathrm{HU}$ and gout based on the most comprehensive literature search until now. Second, the included studies were analysed on the basis of adjusted results and large samples. Third, this study reveals the deficiency of current evidences, which can serve as an indication for further related researches. However, the limitations of this study should also be acknowledged. First, the substantial level of heterogeneity among various studies might have distorted the results of this meta-analysis. Second, owing to the limitation of relevant literature, only a few studies were qualified for this meta-analysis. Third, it is difficult to evaluate the classification of coffee intake. Coffee consumption was mostly assessed by the number of cups of daily coffee intake, but the concentration of each kind of coffee and the cup size could be different among individuals. Fourth, the definitions of outcome and the selection of adjusted factors were not uniform. These limitations might weaken the strengths of this study.

In conclusion, the current evidences are insufficient to prove the association between coffee consumption and a lower risk of HU. Owing to the limited number of studies, the available data show that coffee consumption may be associated with a lower risk of incident gout. Further welldesigned prospective researches and randomised controlled trials are needed to elaborate these issues.

Correction notice This article has been corrected since it was first published. The equal contributors statement has been included on the first page.

Contributors All authors had full access to the data in the study and take responsibility for the integrity of the data and the accuracy of the data analysis. YZ, TY and GL conceived the study objective. YZ, CZ and HL participated in the study design. YZ, Y-IX and XD coordinated the data collection. JW and YY performed the statistical analysis and interpreted the results. All authors helped to outline the manuscript. YZ and TY drafted the manuscript. All authors read and approved the final version.

Funding This work was supported by Fundamental Research Funds for the Central Universities of Central South University (2015zzts296), Hunan Provincial Innovation Foundation for Postgraduate (CX2014A005), the National Natural Science Foundation of China (number 81201420, 81272034, 81472130), the Provincial Science Foundation of Hunan (number 14JJ3032), the Scientific Research Project of the Development and Reform Commission of Hunan Province ((2013) 1199), the Scientific Research Project of Science and Technology Office of Hunan Province (2013SK2018), and the Doctoral Scientific Fund Project of the Ministry of Education of China (20120162110036).
Competing interests None declared.

Ethics approval Systematic review and meta-analysis.

Provenance and peer review Not commissioned; externally peer reviewed.

Data sharing statement No additional data are available.

Open Access This is an Open Access article distributed in accordance with the Creative Commons Attribution Non Commercial (CC BY-NC 4.0) license, which permits others to distribute, remix, adapt, build upon this work noncommercially, and license their derivative works on different terms, provided the original work is properly cited and the use is non-commercial. See: http:// creativecommons.org/licenses/by-nc/4.0/

\section{REFERENCES}

1. Jossa F, Farinaro E, Panico S, et al. Serum uric acid and hypertension: the Olivetti heart study. J Hum Hypertens 1994;8:677-81.

2. Grayson PC, Kim SY, LaValley M, et al. Hyperuricemia and incident hypertension: a systematic review and meta-analysis. Arthritis Care Res (Hoboken) 2011;63:102-10.

3. Kawano Y. Uric acid and blood pressure. Circ J 2011;75:2755-6.

4. Sluijs I, Beulens JW, van Der A DL, et al. Plasma uric acid is associated with increased risk of type 2 diabetes independent of diet and metabolic risk factors. J Nutr 2013;143:80-5.

5. de Oliveira EP, Burini RC. High plasma uric acid concentration: causes and consequences. Diabetol Metab Syndr 2012;4:12.

6. Kim SY, Guevara JP, Kim KM, et al. Hyperuricemia and coronary heart disease: a systematic review and meta-analysis. Arthritis Care Res (Hoboken) 2010;62:170-80.

7. Baker JF, Krishnan E, Chen L, et al. Serum uric acid and cardiovascular disease: recent developments, and where do they leave us? Am J Med 2005;118:816-26.

8. Krishnan E. Hyperuricemia and incident heart failure. Circ Heart Fail 2009;2:556-62.

9. Puddu P, Puddu GM, Cravero E, et al. Relationships among hyperuricemia, endothelial dysfunction, and cardiovascular diseases: molecular mechanisms and clinical implications. J Cardiol 2012;59:235-42.

10. Choi HK, Ford ES. Prevalence of the metabolic syndrome in individuals with hyperuricemia. Am J Med 2007;120:442-7.

11. Filiopoulos V, Hadjiyannakos D, Vlassopoulos D. New insights into uric acid effects on the progression and prognosis of chronic kidney disease. Ren Fail 2012;34:510-20.

12. Yoo TW, Sung KC, Shin HS, et al. Relationship between serum uric acid concentration and insulin resistance and metabolic syndrome. Circ J 2005;69:928-33.

13. Zhu Y, Pandya BJ, Choi HK. Prevalence of gout and hyperuricemia in the US general population: the National Health and Nutrition Examination Survey 2007-2008. Arthritis Rheum 2011;63:3136-41.

14. Uaratanawong S, Suraamornkul S, Angkeaw S, et al. Prevalence of hyperuricemia in Bangkok population. Clin Rheumatol 2011;30:887-93.

15. Roddy E, Doherty M. Epidemiology of gout. Arthritis Res Ther 2010;12:223.

16. Miao Z, Li C, Chen Y, et al. Dietary and lifestyle changes associated with high prevalence of hyperuricemia and gout in the Shandong coastal cities of Eastern China. J Rheumatol 2008;35:1859-64.

17. Naqahama K, Iseki K, Inoue T, et al. Hyperuricemia and cardiovascular risk factor clustering in a screened cohort in Okinawa Japan. Hypertens Res 2004;27:227-33.

18. Lin SD, Tsai DH, Hsu SR. Association between serum uric acid leve and components of the metabolic syndrome. J Chin Med Assoc 2006;69:512-16.

19. Choi HK, Mount DB, Reginato AM. Pathogenesis of gout. Ann Intern Med 2005;143:499-516.

20. Yu KH, See LC, Huang YC, et al. Dietary factors associated with hyperuricemia in adults. Semin Arthritis Rheum 2008;37:243-50.

21. Iso $\mathrm{H}$, Date $\mathrm{C}$, Wakai $\mathrm{K}$, et al. The relationship between green tea and total caffeine intake and risk for self-reported type 2 diabetes among Japanese adults. Ann Intern Med 2006;144:554-62.

22. Salazar-Martinez E, Willett WC, Ascherio A, et al. Coffee consumption and risk for type 2 diabetes mellitus. Ann Intern Med 2004;140:1-8.

23. Higdon JV, Frei B. Coffee and health: a review of recent human research. Crit Rev Food Sci Nutr 2006;46:101-23.

24. Qi H, Li S. Dose-response meta-analysis on coffee, tea and caffeine consumption with risk of Parkinson's disease. Geriatr Gerontol Int 2014;14:430-9. 
25. Ding M, Bhupathiraju SN, Satija A, et al. Long-term coffee consumption and risk of cardiovascular disease: a systematic review and a dose-response meta-analysis of prospective cohort studies. Circulation 2014;129:643-59.

26. Wang S, Zhang Y, Mao Z, et al. A meta-analysis of coffee intake and risk of urolithiasis. Urol Int 2014;93:220-8.

27. Jiang $X$, Zhang $D$, Jiang $W$. Coffee and caffeine intake and incidence of type 2 diabetes mellitus: a meta-analysis of prospective studies. Eur J Nutr 2014;53:25-38.

28. Wu W, Tong Y, Zhao Q, et al. Coffee consumption and bladder cancer: a meta-analysis of observational studies. Sci Rep 2015;12:9051.

29. James JE. Critical review of dietary caffeine and blood pressure: a relationship that should be taken more seriously. Psychosom Med 2004:66:63-71.

30. Jee $\mathrm{SH}, \mathrm{He} J$, Appel LJ, et al. Coffee consumption and serum lipids: a meta-analysis of randomized controlled clinical trials. $A m \mathrm{~J}$ Epidemiol 2001;153:353-62.

31. Grubben MJ, Boers GH, Blom HJ, et al. Unfiltered coffee increases plasma homocysteine concentrations in healthy volunteers: a randomized trial. Am J Clin Nutr 2000;71:480-4.

32. De Muckadell BO, Gyntelberg F. Occurrence of gout in Copenhagen males aged 40-59. Int $J$ Epidemiol 1976;5:153-8.

33. Curb JD, Reed DM, Kautz JA, et al. Coffee, caffeine, and serum cholesterol in Japanese men in Hawaii. Am J Epidemiol 1986;123:648-55.

34. Kiyohara C, Kono S, Honjo S, et al. Inverse association between coffee drinking and serum uric acid concentrations in middle-aged Japanese males. Br J Nutr 1999;82:125-30.

35. Yuan SC, Wang CJ, Kuo HW, et al. Effect of tea and coffee consumption on serum uric acid levels by liquid-chromatographic and uricase methods. B Environ Contam Tox 2000;65: 300-6.

36. Choi HK, Curhan G. Coffee, tea, and caffeine consumption and serum uric acid level: the Third National Health and Nutrition Examination Survey. Arthritis Rheum 2007;57:816-21.

37. Choi HK, Willett W, Curhan G. Coffee consumption and risk of incident gout in men. A prospective study. Arthritis Rheum 2007;56:2049-55.

38. Choi HK, Curhan G. Coffee consumption and risk of incident gout in women: the Nurses' Health Study. Am J Clin Nutr 2010;92:922-7.

39. Pham NM, Yoshida D, Morita M, et al. The relation of coffee consumption to serum uric acid in Japanese men and women aged 49-76 years. J Nutr Metab 2010;2010:930757.
40. Chuang SY, Lee SC, Hsieh YT, et al. Trends in hyperuricemia and gout prevalence: Nutrition and Health Survey in Taiwan from 19931996 to 2005-2008. Asia Pac J Clin Nutr 2011;20:301-8.

41. Teng GG, Tan CS, Santosa A, et al. Serum urate levels and consumption of common beverages and alcohol among Chinese in Singapore. Arthritis Care Res (Hoboken) 2013;65:1432-40.

42. Bae J, Park PS, Chun BY, et al. The effect of coffee, tea, and caffeine consumption on serum uric acid and the risk of hyperuricemia in Korean Multi-Rural Communities Cohort. Rheumatol Int 2015;35:327-36.

43. Kela U, Vijayvargiya R, Trivedi CP. Inhibitory effects of methylxanthines on the activity of xanthine oxidase. Life Sci 1980;27:2109-19.

44. Liberati A, Altman DG, Tetzlaff J, et al. The PRISMA statement for reporting systematic reviews and meta-analyses of studies that evaluate healthcare interventions: explanation and elaboration. BMJ 2009;339:b2700.

45. Wells GA, Shea B, O'Connell D, et al. The Newcastle-Ottawa Scale (NOS) for assessing the quality of nonrandomized studies in meta-analyses. 2010. http://www.ohri.ca/programs/clinical_ epidemiology/oxford.asp

46. Begg CB, Mazumdar M. Operating characteristics of a rank correlation test for publication bias. Biometrics 1994;50:1088-101.

47. Strandhagen E, Thelle DS. Filtered coffee raises serum cholesterol: results from a controlled study. Eur J Clin Nutr 2003;57:1164-8.

48. Shang F, Li X, Jiang X. Coffee consumption and risk of the metabolic syndrome: a meta-analysis. Diabetes Metab 2016;42:80-7.

49. Liu Z, Que S, Zhou L, et al. Dose-response relationship of serum uric acid with metabolic syndrome and non-alcoholic fatty liver disease incidence: a meta-analysis of prospective studies. Sci Rep 2015;5:14325

50. Choi JW, Ford ES, Gao X, et al. Sugar-sweetened soft drinks, diet soft drinks, and serum uric acid level: the Third National Health and Nutrition Examination Survey. Arthritis Rheum 2008;59:109-16.

51. Choi HK, Liu S, Curhan G. Intake of purine-rich foods, protein, and dairy products and relationship to serum levels of uric acid: the Third National Health and Nutrition Examination Survey. Arthritis Rheum 2005;52:283-9.

52. Choi HK, Atkinson K, Karlson EW, et al. Purine-rich foods, dairy and protein intake, and the risk of gout in men. $N$ Engl J Med 2004;350:1093-103.

53. Amin R, Alyasin S, Rahmani G. Theophylline-induced alteration in serum electrolytes and uric acid of asthmatic children. Iran J Allergy Asthma Immunol 2003;2:31-7. 
Correction: Is coffee consumption associated with a lower risk of hyperuricaemia or gout? A systematic review and meta-analysis

Zhang Y, Yang T, Zeng C, et al. Is coffee consumption associated with a lower risk of hyperuricaemia or gout? A systematic review and meta-analysis. BMJ Open 2016;6: e009809. This article has been resupplied. The equal contributors statement has been included on the first page.

Open Access This is an Open Access article distributed in accordance with the Creative Commons Attribution Non Commercial (CC BY-NC 4.0) license, which permits others to distribute, remix, adapt, build upon this work noncommercially, and license their derivative works on different terms, provided the original work is properly cited and the use is non-commercial. See: http://creativecommons.org/licenses/by-nc/4.0/

BMJ Open 2016;6:e009809corr1. doi:10.1136/bmjopen-2015-009809corr1

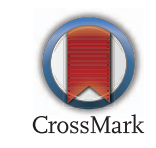

